\title{
Association of Cytokine TNF-a in Development of Osteoarthritis: A Comprehensive Study
}

\author{
AmitKumar ${ }^{1}$, Md Arshad ${ }^{2}$, Ajai Singh ${ }^{3}$, Habiba Khan² and Suchit Swaroop ${ }^{1 *}$ \\ ${ }^{1}$ Department of Zoology, Experimental and Public Health Laboratory, University of Lucnow, Lucknow - 226007, India \\ 2Department of Zoology, Molecular Endocrinology Lab, University of Lucknow, Lucknow - 226007, India \\ 32Department of Orthopaedics, King George Medical University, Lucknow - 226003, India; ephlablkouni@gmail.com
}

\begin{abstract}
Osteo-Arthritis $(\mathrm{OA})$ is a disease of joints affecting the normal functions of joint and causes physical disability. Many factors are responsible for development of osteoarthritis including over age, obesity, gender, drug abuse, over load on joints and genetic factors. OA causes health problems and impairs the quality of life with increased economic burden across the world. Apart from the pro-inflammatory role of cytokine Interleukin-1 (IL-1) in osteoarthritis, Tumor necrosis factor-alpha (TNF- $\alpha$ ) is also involved in the progression of osteoarthritis. Members of TNF family are secreted from lymphocytes and natural killer cells but in OA patients it is also secreted from chondrocyte cells to influence the catabolic processes in Extra Cellular Matrix (ECM) by inducing the activity of matrix metaloproteinases (MMPs). In promoter region, most of the Single nucleotide polymorphisms (SNPs) of TNF- $\alpha$ located on -863, $-857,-308$, and -238 . These SNPs are involved in various diseases including OA, rheumatoid Arthritis, systemic lupus erythematosus etc. Significance association of SNP -G308A of the TNF- $\alpha$ gene in OA has been observed in various studies. Aim of this mini review is to conclude the fundamental roles of TNF- $\alpha$ cytokine in patients with OA.
\end{abstract}

Keywords: Cytokine, Gene Variants, Osteoarthritis, Pathophysiology, TNF- $\alpha$

\section{Introduction}

Osteoarthritis is age related joint disease that adversely affects the normal daily activities of life in elderly population. It is marked by continuous breakdown of articular cartilage and other components of joints ${ }^{1}$. Italso leads to development of osteophyte. OA may affect almost all joints (hip, hand, knee etc) whereas in an obese person knee $\mathrm{OA}$ is most common. Females have slightly higher prevalence of developing $\mathrm{OA}$ as compared to males, females aged fifty and above suffer mostly from hand $\mathrm{OA}^{17}$. Among pro-inflammatory cytokines, both IL-1 $\beta$ and TNF-ahave predominant roles in destruction of healthy cartilage by inducing some proteases ${ }^{20}$. Two important cells of joint viz. chondrocyte and synovial cell secretes these pro-inflammatory cytokines in extracellular spaces, where they induce inflammatory response ${ }^{18}$. Anti-inflammatory cytokines such as IL-4, IL-10, IL-13 inhibit the action of pro-inflammatory cytokines ${ }^{30}$. Developing OA is marked by over expression of degradative enzymes and pro-inflammatory cytokines. Most common enzymes in synovial fluid are Matrix MetalloProteinases (MMPs), aggrecanases ${ }^{37}$. It can be very difficult to understand about concentrations of pro-inflammatory cytokines because some patients show high concentrations whereas in others show low concentrations. Due to this reason, cytokines remain controversial.
Over the years, many studies have reviled that the genetic susceptibility strongly contributing in pathophysiology of OA development. High levels of pro-inflammatory cytokines in synovial fluid of OA patients indicate the breakdown of cartilage and progression of disease ${ }^{18}$. Members of TNF-family are predominantly synthesised by immune cells (B and T lymphocytes), NK-cells. It has been also reported that theses cytokines concentration also high in synovial fluid in OA patients (O'Rourke et al., 2008). TNF- $\alpha$ encoding gene is present at most polymorphic region of DNA, where the major histocompatibility complex type-III (MHC-III) gene is located ${ }^{12}$. Number of gene variants of TNF- $\alpha$ increase the susceptibility in OA. Aim of this study to explore the impact of TNF- $\alpha$ cytokine and their gene variants in development of OA.

\section{Role of TNF-a in Pathophysiology of Osteoarthritis}

TNF- $\alpha$ is a pro-inflammatory cytokine which plays a role in pathophysiology of $\mathrm{OA}^{34}$. It is a $17 \mathrm{kDa}$ secreted protein by activated chondrocyte, macrophage and other cells which affects the synthesis of onthercytokines such as IL-1 and IL- 89 . TNF- $\alpha$ along with IL- $1 \beta$ involved in etiology of the disease. It is one of the 19 members of Tumor Necrosis Factor (TNF)

${ }^{*}$ Author for correspondence 
superfamily ${ }^{5}$. TNF- $\alpha$ is primarily composed of three identical transmembrane proteins Type II (mTNFa) and later TACE/ ADAM17 metalloproteinase cause maturation of mTNFa into soluble free TNF- $\alpha$ (sTNF- $\alpha$ ), which is secreted out by the cell ${ }^{11}$. Both IL- $1 \beta$ and TNF- $\alpha$ are secreted from same cell of the joint.

TNF- $\alpha$ is mainly synthesized in synovial chondrocyte cells. Elevated level of TNF- $\alpha$ was detected in synovial membrane, cartilage tissue, sub-chondral bone layer ${ }^{7}$. TNF- $\alpha$ has affinity to interact with two receptor isotypes (TNF-R1 and TNFR2). These receptors are expressed on membrane of about all nucleated cells ${ }^{22}$. The receptor TNF-R1 can be stimulated by the soluble as well as membrane forms ligand whereas receptor TNF-R2 only recognises membrane form of ligand. Thus, the receptor TNF-R1 has higher impact on cartilage breakdown than of receptor TNF-R2 ${ }^{22}$. Elevated expression of TNF-R1 has also observed in Fibroblast-like synoviocyte ${ }^{25}$. Structurally TNF-R1 and TNF-R2 are unrelated with their carboxyl terminal domain. TNF-R1 has associated with Death Domain (DD) in their carboxyl terminal which lack in TNF$\mathrm{R} 2{ }^{11}$. Insight the intracellular dissimilarity between these two receptors, they relay different signal from outside of the cell to the nucleus. Signal transduction through TNF-R1 is involved by formation of two complexes. The complex-1 is inherent in the expression of proteins responsible for prevention of apoptosis and secretion of inflammatory cytokine whereas second complex is directly involving in signal transduction and fragmentation of cell ${ }^{35}$. The binding of TNF- $\alpha$ to TNF$\mathrm{R} 1$ leads to interaction of carboxyl terminus (Death Domain) with adapter proteins such as TRADD, TRAF, c-IAP1, c-IAP2 and RIP ${ }^{6}$. This interaction results in proteasomal degradation of RIP1 protein and interaction with other proteins such as TAB1, TAB2 and TAK. Subsequently, the phosphorylation of IKK protein takes place which is associated with NEMO protein. IKK is responsible of activation of most important transcription factor NF-kB ${ }^{21}$. During activation of complex-1 other pathway also triggered involving JaNus Kinase (JNK), Extracellular Regulated Kinase (ERK) and Mitogen Activated Protein Kinase (MAPK) ${ }^{14,38}$. Activation of complex-2 through TNF-R1 results in endocytosis of receptor and interaction with FADD and subsequently activation of pro-caspases- 8 into activated caspases- 8 . This pathway finished with cell death ${ }^{28}$. After the formation of complex of mTNF- $\alpha$ and TNF$\mathrm{R} 2$, interaction of adopter proteins such as TRAF2, TRAF3, RIP1, c-IAP1 and c-IAP2 with receptor occur and proteosomal degradation of RIP1 takes place. End responses through this signal are the activation of transcription factor NF-kb and $\mathrm{AP}^{24}$ (Figure 1).

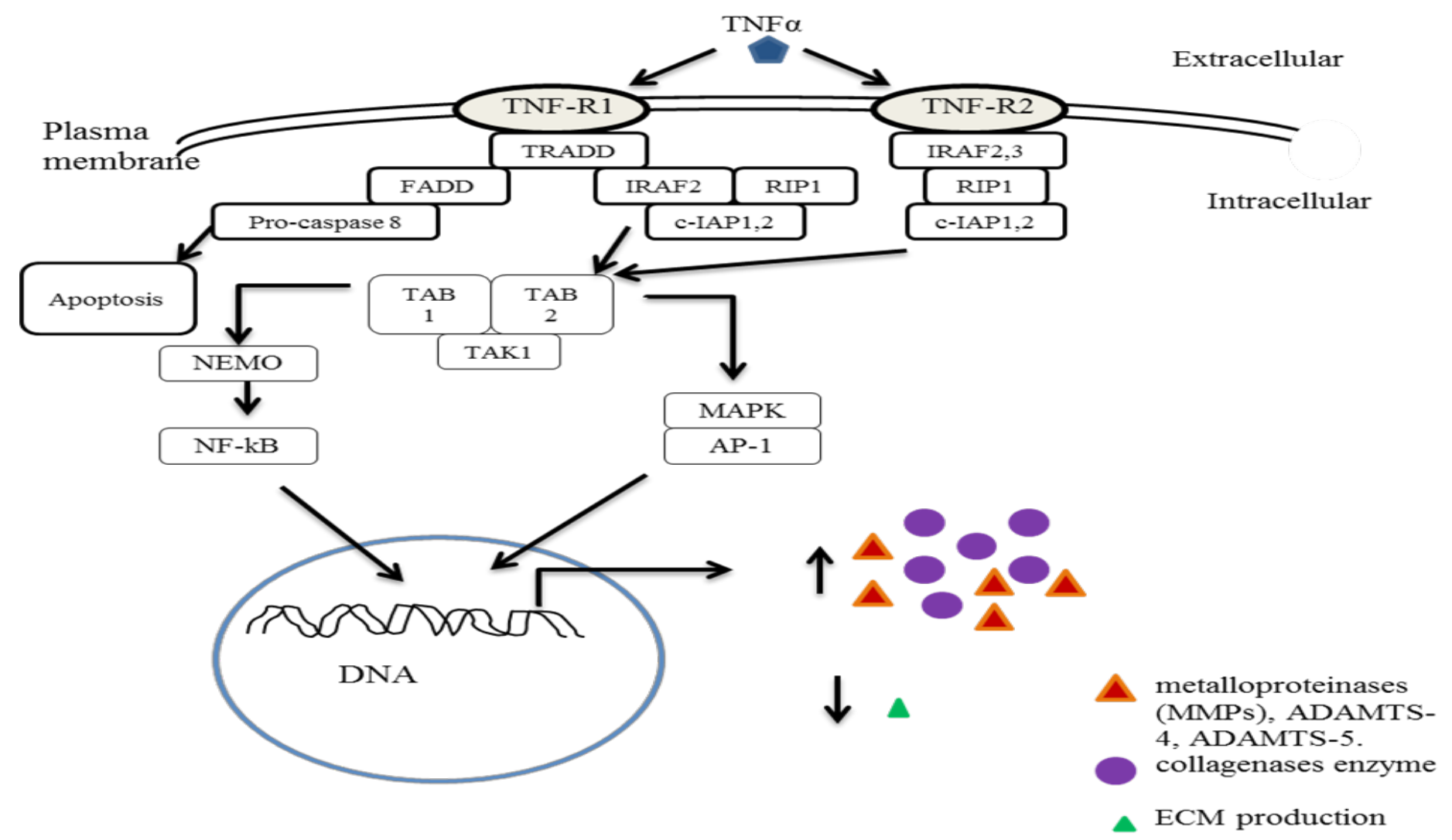

Figure 1. Intra cellular signaling pathway of TNF- $\alpha$ in OA 
The final responses are the production of metalloproteinases (MMPs), ADAMTS4, ADAMTS-5, collagenases and inhibition of Extra Cellular Matrix (ECM) components production. Tumor necrosis factor- $\alpha$ receptor 1 (TNF- $\alpha$ R 1), Tumor necrosis factor- $\alpha$ receptor2 (TNF- $\alpha$ R2), Tumor necrosis factor receptor type 1 associated death domain protein (TRADD; Fas-Associated protein with Death Domain (FADD); TNF receptor-associated factor 6 (IRAF6); c-IAP also called BIRC3 (Baculovirus IAP repeat-containg protein3).Receptorinteracting protein kinase 1 (RIP1); TAB1 is also known as mitogen-activated protein kinase kinasekinase 7 inactivating protein 1(MAP3K7IP1) and TAB2 is also known as mitogenactivated protein kinase kinasekinase 7 inactivating protein 2(MAP3K7IP2); TAK is a mitogen-activated protein kinase kinasekinase 7(MAP3K7); NF-kB essential modulator/NF-kB inhibitor kinase1,2 (NEMO/IKK1,2); mitogen-activated protein kinase (MAPK); basal transcription activating protein called activator protein-1 (AP-1).

The catabolic effect of TNF- $\alpha$ leads to cartilage breakdown and also induces the sensory neurons through the TNF- $\alpha$ receptor 1, 2 (TNFR1 and TNFR2). TNF- $\alpha$ induced neuropathic pain may be treated by application of anti-inflammatory medications. Ibuprofen and celecoxib are known to reduce the pain through their anti-inflammatory properties ${ }^{32}$. It causes initiation of events of cascade in inflammatory reactions with other pro-inflammatory cytokines such as IL- $1 \beta$, IL-6 etc ${ }^{3}$. Both TNF- $\alpha$ and IL-1 $\beta$ are involved synergistically in in many cases during course of OA. These cytokines are sharing some cytosolic events and trigger the catabolic phenomenon and inflammation during development of $\mathrm{OA}^{16}$ TNF- $\alpha$ is affecting the function of chondrocyte, blocking the production of extracellular components such as collagen type 2, proteogly$\mathrm{can}^{15}$. Activated chondrocytes are increasing the expression of extracellular components degradative enzymes include MMPs and ADAMTS- $4^{29}$. Chondrocyte apoptosis and migration of CPCs (Chondrogenic progenitor cells) will results in reduction of any chance of reappearing of normal articular cartilage ${ }^{10}$. Both TNF- $\alpha$ and IL- $1 \beta$ also disrupt the normal functioning of mitochondria and causes reduction in ATP synthesis hence, less energetic chondrocyte cell will also loss the mitochondrial membrane permeability ${ }^{23}$.

\section{Gene Variants of TNF- $a$ in Osteoarthritis}

Gene for TNFa cytokine is located in core region of major histocompatibility complex. This gene encodes one of the most important proinflammatory cytokine is known as TNFa. This cytokine plays important role in cartilage damage of healthy joints especially in hand and knee. A study on Han Chinese population articulated that allele 'A' of TNF- $\alpha-308$ variant has an impact on risk of OA however,rs361525 SNP of TNF- $\alpha-238$ has no impact on same population with $\mathrm{OA}^{4}$. HLA (Human leucocyte antigen)-class II/III region and TNF- $\alpha$ gene, where some SNPs such as rs7775228 and rs10947262 were found to be associated with knee $\mathrm{OA}^{27,33}$.

Recent study in Finnish women population was suggested that TNFa gene variants play crucial function in etiological process of hand OA. Both haplotype and minor alleles poisoned at -1031 and -863 of the TNFa were involved independently in risk of hand $\mathrm{OA}^{31}$. Another study has been done in Egyptian female with severity of early onset knee OA suggested that TNF- $\alpha-G 308$ A polymorphism involved in susceptibility to disease progression ${ }^{2}$.

Human Leucocyte Antigen (HLA) class-II and class-III consist of some variants of TNF- $\alpha$ gene which include rs7775228 and rs10947262. It has been observed that these variants are strongly associated with possibility to develop knee $\mathrm{OA}^{27,33}$. As per high level of expression of TNF- $\alpha$ with -308A allele and low expression of $-308 \mathrm{G}$ allele, meta-analysis concluded that $\mathrm{AA}$ and $\mathrm{AG}$ genotypes influence the rate of risk of $\mathrm{OA}$, whereas individuals with GG genotype might have lesser impact on developing of $\mathrm{OA}^{19}$. Among other variants of TNF- $\alpha$, the minor allele of the "-308" locus is affecting the TNF-a protein expression under various stimuli ${ }^{36}$. Results of some previous studies unclear the association of gene variants of TNF- $\alpha$ with $\mathrm{OA}^{13}$. It was found that TNF- $\alpha$ can perform function independently in OA or in association with other cytokines such as IL-1 $\beta$, IL-6 etc ${ }^{18}$. The locus "-1082" polymorphism of IL-10 inhibits the synthesis and production of TNF- $\alpha$. IL-10 is an anti-inflammatory cytokine might be opposing the function of TNF- $\alpha$ in $\mathrm{OA}^{8}$.

\section{Conclusion}

OA is considered as one of the most prevalent joint disorder in elderly population worldwide. It commonly affects knee and hand joints but other joints also affected with limited function. It affects the daily activity of an individual who are susceptible to OA. Among other risk factors, proinflammatory cytokines such as IL-1, TNF- $\alpha$ are involved in progression of disease. During onset of OA, elevated levels of these cytokines observed in synovial fluid.

The TNF- $\alpha$ along with IL- $1 \beta$ plays important role in cartilage destruction in joints and leads to progression of OA. Remodelling of joint bone also influence by these cytokines. After binding of TNF- $a$ with their receptors, it activates proinflammatory signal cascade through different cytosolic kinases and transcription factors.

In continue, proinflammatory cytokines directly force the expression of proteolytic enzymes such as collagenases and others in the synovial fluid of joints. These enzymesare 
responsible for breakdown of healthy cartilage and extra cellular matrix components of joint and leads to narrowing of joint space $^{37}$. This will result in friction of two bone terminus and inflammation.

The gene variants of TNF- $\alpha$ are located in MHC protein encoding region. Among other variants of TNF- $\alpha$, the locus "-308" has been involved in susceptibility of disease ${ }^{4}$ that reported in many studies over decay.

\section{References}

1. Kumar A, Arshad M, Singh A, Jafri A, Ali S, Yadav M, Swaroop S. Role of Interleukin-1 Super Family in Progression of Osteoarthritis, Journal of Ecophysiology and Occupational Health. 2017; 17:9-16.

2. Galil SMA, Ezzeldin N, Fawzy F, El-Boshy M. The SingleNucleotide Polymorphism (SNP) of tumor necrosis factor a- 308G/A gene is associated with early-onset primary knee osteoarthritis in an Egyptian female population, Clinical Rheumatology. 2017; 36:2525-30. https://doi.org/10.1007/ s10067-017-3727-1. PMid: 28695434.

3. Aoki Y, Ohtori S, Ino H, Douya H, Ozawa T, Saito T, Takahashi K. Disc inflammation potentially promotes axonal regeneration of dorsal root ganglion neurons innervating lumbar intervertebral disc in rats, Spine. 2004; 29:2621-26. https://doi.org/10.1097/01. brs.0000146051.11574.b4. PMid:15564910.

4. Ji B, Shi J, Cheng X, Zhou J, Zhou Q, Cao C, Pang J. Association analysis of two candidate polymorphisms in the tumour necrosis factor- $\alpha$ gene with osteoarthritis in a Chinese population, International Orthopaedics. 2013; 37:2061-63. https://doi. org/10.1007/s00264-013-1931-4. PMid: 23748461, PMCid: PMC3779584.

5. Bodmer JL, Schneider P, Tschopp J. The molecular architecture of the TNF superfamily, Trends in Biochemical Sciences. 2002; 27:19-26. https://doi.org/10.1016/S0968-0004(01)01995-8.

6. Varfolomeev E, Goncharov T, Fedorova AV, Dynek JN, Zobel K, Deshayes K, Vucic D. c-IAP1 and c-IAP2 are critical mediators of tumor necrosis factor a (TNFa)-induced NF- $\kappa \mathrm{B}$ activation, Journal of Biological Chemistry. 2008; 283:24295-99. https:// doi.org/10.1074/jbc.C800128200. PMid: 18621737, PMCid: PMC3259840.

7. Farahat MN, Yanni G, Poston R, Panayi GS. Cytokine expression in syno-vial membranes of patients with rheumatoid arthritis and osteoarthritis, Annals of the Rheu-Matic Diseases. 1993; 52:870. https://doi.org/10.1136/ard.52.12.870.

8. Fernandes JC, Martel-Pelletier J, Pelletier JP. The role of cytokines in os-teoarthritis pathophysiology, Biorheology. 2002; 39:237-46. PMid: 12082286.

9. Guerne PA, Carson DA, Lotz M. IL-6 production by human articular chon-drocytes.Modulation of its synthesis by cytokines, growth factors, and hormones in vitro, The Journal of Immunology. 1990; 144:499-505. PMid: 2104896.
10. Joos H, Wildner A, Hogrefe C, Reichel H, Brenner RE. Interleukin-1 beta and tumor necrosis factor alpha inhibit migration activity of chondrogenic progenitor cells from non-fibrillated osteoarthritic cartilage, Arthritis Research and Therapy. 2013; 15:R119. https://doi.org/10.1186/ar4299. PMid: 24034344, PMCid: PMC3978440.

11. Idriss HT, Naismith JH. TNFa and the TNF receptor superfamily: Struc-ture-function relationship (s)", Microscopy Research and Technique. 2000; 50:184-95. https://doi.org/10.1002/10970029(20000801)50:3<184::AID-JEMT2>3.0.CO;2-H.

12. Hajeer AH, Hutchinson IV. TNF-a gene polymorphism: Clinical and bio-logical implications, Microscopy Research and Technique. 2000; 50:216-28. https://doi.org/10.1002/10970029(20000801)50:3<216::AID-JEMT5>3.0.CO;2-Q.

13. Han L, Song JH, Yoon JH, Park YG, Lee SW, Choi YJ, ... Park WS. TNF- $\alpha$ and TNF- $\beta$ Polymorphisms are Associated with Susceptibility to Osteoarthri-tis in a Korean Population, Korean Journal of Pathology. 2012; 46:30. https://doi.org/10.4132/ KoreanJPathol.2012.46.1.30. PMid: 23109975, PMCid: PMC3479703.

14. Campbell J, Ciesielski CJ, Hunt AE, Horwood NJ, Beech JT, Hayes LA, ... Foxwell BM. A novel mechanism for TNF- $\alpha$ regulation by p38 MAPK: In-volvement of NF- $\kappa B$ with implications for therapy in rheumatoid arthritis, The Journal of Immunology. 2004; 173:6928-37. https://doi.org/10.4049/jimmunol.173.11.6928. PMid: 15557189.

15. Xue J, Wang J, Liu Q, Luo A. Tumor necrosis factor- $\alpha$ induces ADAMTS-4 expression in human osteoarthritis chondrocytes, Molecular Medicine Reports. 2013; 8:1755-60. https://doi. org/10.3892/mmr.2013.1729. PMid: 24126638.

16. Marcu BK, Otero M, Olivotto E, Maria Borzi R, Goldring BM. NF- $\kappa B$ sig-naling: Multiple angles to target $\mathrm{OA}$, Current Drug Targets. 2010; 11:599-613. https://doi. org/10.2174/138945010791011938. PMid: 20199390, PMCid: PMC3076145

17. Kalichman L, Hernández-Molina G. Hand osteoarthritis: An epidemiological perspective, In Seminars in Arthritis and Rheumatism. 2010; 39:465-76. https://doi.org/10.1016/j.semarthrit.2009.03.001. PMid: 19482338.

18. Kapoor M, Martel-Pelletier J, Lajeunesse D, Pelletier JP, Fahmi H. Role of proinflammatory cytokines in the pathophysiology of osteoarthritis, Nature Reviews Rheu-matology. 2011; 7:33. https://doi.org/10.1038/nrrheum.2010.196. PMid: 21119608.

19. Kou S, Wu Y. Meta-analysis of tumor necrosis factor alpha308 polymorphism and knee osteoarthritis risk, BMC Musculoskeletal Disorders. 2014; 15:373. https://doi. org/10.1186/1471-2474-15-373. PMid: 25398219, PMCid: PMC4289255.

20. Krasnokutsky S, Attur M, Palmer G, Samuels J, Abramson SB. Current concepts in the pathogenesis of osteoarthritis, Osteoarthritis and Cartilage. 2008; 16:S1-S3. https://doi. org/10.1016/j.joca.2008.06.025. PMid: 18723377. 
21. O’Donnell MA, Legarda-Addison D, Skountzos P, Yeh WC, Ting AT. Ubiquitination of RIP1 regulates an NF- $\kappa B$-independent cell-death switch in TNF signal-ing, Current Biology. 2007; 17:418-24. https://doi.org/10.1016/j.cub.2007.01.027. PMid: 17306544, PMCid: PMC1868513.

22. Grell M, Douni E, Wajant H, Löhden M, Clauss M, Maxeiner $\mathrm{B}, \ldots$ Scheurich $\mathrm{P}$. The transmembrane form of tumor necrosis factor is the prime activating ligand of the $80 \mathrm{kDa}$ tumor necrosis factor receptor, Cell. 1995; 83:793-802. https://doi. org/10.1016/0092-8674(95)90192-2.

23. Lopez-Armada MJ, Carames B, Martin MA, Cillero-Pastor B, Lires-Dean M, Fuentes-Boquete I, ... Blanco FJ. Mitochondrial activity is modulated by TNFa and IL- $1 \beta$ in normal human chondrocyte cells, Osteoarthritis and Cartilage. 2006; 14:1011-22. https://doi.org/10.1016/j.joca.2006.03.008. PMid: 16679036.

24. Rodríguez M, Cabal-Hierro L, Carcedo MT, Iglesias JM, Artime $\mathrm{N}$, Darnay BG, Lazo PS. NF- $\kappa \mathrm{B}$ signal triggering and termination by tumor necrosis factor re-ceptor 2, Journal of Biological Chemistry. 2011; 286:22814-24. https://doi.org/10.1074/jbc. M111.225631. PMid: 21558270, PMCid: PMC3123049.

25. Steenvoorden MMC, Bank RA, Ronday HK, Toes REM, Huizinga TWJ, DeGroot J. Fibroblast-like synoviocyte-chondrocyte interaction in cartilage degra-dation, Clinical and Experimental Rheumatology. 2007; 25:239. PMid: 17543148.

26. Munoz-Valle JF, Oregón-Romero E, Rangel-Villalobos H, Martínez-Bonilla GE, Casta-eda-Saucedo E, Salgado-Goytia L, ... Parra-Rojas I. High expression of TNF alpha is associated with308 and- 238 TNF alpha polymorphisms in knee osteoarthri-tis, Clinical and Experimental Medicine. 2014; 14:61-67. https://doi. org/10.1007/s10238-012-0216-3. PMid: 23108479.

27. Nakajima M, Takahashi A, Kou I, Rodriguez-Fontenla C, GomezReino JJ, Furuichi T, ... Kubo M. New sequence variants in HLA class II/III region associated with susceptibility to knee osteoarthritis identified by genome-wide association study, PloS One. 2010; 5:e9723. https://doi.org/10.1371/journal.pone.0009723. PMid: 20305777, PMCid: PMC28411.

28. Micheau O, Tschopp J. Induction of TNF receptor I-mediated apoptosis via two sequential signaling complexes, Cell. 2003; 114:181-90. https://doi.org/10.1016/S0092-8674(03)00521-X.

29. Verma P, Dalal K. ADAMTS-4 and ADAMTS-5: Key enzymes in osteoarthri-tis, Journal of Cellular Biochemistry. 2011; 112:3507-14. https://doi.org/10.1002/jcb.23298. PMid: 21815191.

30. Thomas DP, King B, Stephens T, Dingle JT. In vivo studies of cartilage regeneration after damage induced by catabolin/inter- leukin-1, Annals of the Rheumatic Dis-eases. 1991; 50:75-80. https://doi.org/10.1136/ard.50.2.75.

31. Hämäläinen $S$, Solovieva $S$, Vehmas T, Leino-Arjas $P$, Hirvonen A. Variations in the TNFa gene and their interactions with the IL4R and IL10 genes in relation to hand osteoarthritis, BMC Musculoskeletal Disorders. 2014; 15:311. https://doi. org/10.1186/1471-2474-15-311. PMid: 25252624, PMCid: PMC4181701.

32. Schäfers $M$, Marziniak M, Sorkin LS, Yaksh TL, Sommer C. Cyclooxy-genase inhibition in nerve-injury-and TNFinduced hyperalgesia in the rat, Experimental Neurology. 2004; 185:160-68. https://doi.org/10.1016/j.expneurol.2003.09.015. PMid: 14697327

33. Shi, D., Zheng, Q., Chen, D., Zhu, L., Qin, A., Fan, J., ...\&Xu, J. (2010) "Association of sin-gle-nucleotide polymorphisms in HLA class II/III region with knee osteoarthri-tis", Osteoarthritis and cartilage, 18, 1454-1457. https://doi.org/10.1016/j. joca.2010.07.009. PMid: 20691797.

34. Sommer C, Kress M. Recent findings on how proinflammatory cytokines cause pain: peripheral mechanisms in inflammatory and neuropathic hyperalgesia, Neuroscience Letters. 2004; 361:184-87. https://doi.org/10.1016/j.neulet.2003.12.007. PMid: 15135924.

35. Haas TL, Emmerich CH, Gerlach B, Schmukle AC, Cordier SM, Rieser E, ... Koschny R. Recruitment of the linear ubiquitin chain assembly complex stabilizes the TNF-R1 signaling complex and is required for TNF-mediated gene induction, Molecular Cell. 2009; 36:831-44. https://doi.org/10.1016/j.molcel.2009.10.013. PMid:20005846.

36. Wilson AG, Symons JA, McDowell TL, McDevitt HO, Duff GW. Ef-fects of a polymorphism in the human tumor necrosis factor a promoter on transcriptional activation, Proceedings of the National Academy of Sciences. 1997; 94:3195-99. https://doi. org/10.1073/pnas.94.7.3195.

37. Yoshihara Y, Nakamura H, Obata KI, Yamada H, Hayakawa T, Fujikawa K, Okada Y. Matrix metalloproteinases and tissue inhibitors of metalloproteinases in synovial fluids from patients with rheumatoid arthritis or osteoarthritis, Annals of the Rheu-Matic Diseases. 2000; 59:455-61. https://doi.org/10.1136/ard.59.6.455. PMCid:PMC1753174.

38. Zhou Z, Connell MC, MacEwan DJ. TNFR1-induced NF- $\kappa B$, but not ERK, p38MAPK or JNK activation, mediates TNF-induced ICAM-1 and VCAM-1 expression on endothelial cells, Cellular Signalling. 2007; 19:1238-48. https://doi.org/10.1016/j.cellsig.2006.12.013. PMid: 17292586. 